\title{
Population Fluctuation and Vertical Distribution of the Soybean Looper (Chrysodeixis includens) in Soybean Culture
}

\author{
Daniele Zulin¹, Crébio J. Ávila², Eunice C. Schlick-Souza ${ }^{3}$ \\ ${ }^{1}$ Postgraduate Program in Entomology and Biodiversity Conservation, Universidade Federal da Grande Dourados, Dourados-MS, \\ Brazil \\ ${ }^{2}$ Embrapa Agropecuária Oeste, Dourados-MS, Brazil \\ ${ }^{3}$ Instituto Federal de Mato Grosso, Campo Novo do Parecis-MT, Brazil \\ Email: euniceschlick@hotmail.com
}

How to cite this paper: Zulin, D., Ávila, C.J. and Schlick-Souza, E.C. (2018) Population Fluctuation and Vertical Distribution of the Soybean Looper (Chrysodeixis includens) in Soybean Culture. American Journal of Plant Sciences, 9, 1544-1556. https://doi.org/10.4236/ajps.2018.97113

Received: April 25, 2018

Accepted: June 25, 2018

Published: June 28, 2018

Copyright $\odot 2018$ by authors and Scientific Research Publishing Inc. This work is licensed under the Creative Commons Attribution International License (CC BY 4.0).

http://creativecommons.org/licenses/by/4.0/

\begin{abstract}
The objective of this work was to study the population fluctuation and the vertical distribution of the Chrysodeixis includens (Walker) (Lepidoptera: Noctuidae) in the leaf canopy of soybeans. The experiments were conducted under field conditions in the experimental area of the Embrapa Agropecuária Oeste during the 2014/2015 harvest. Adult monitoring was performed using Delta-type traps, baited with the pest sexual pheromone. The eggs were collected in the soybean plants and the caterpillars monitored through the beat cloth. The population peaks of $C$. includens occurred in the reproductive period of the soybean plants, although the adults were also found in the season soybean. Although there was no significant relationship between the trapped adults and the immature forms of $C$. includens sampled with the beat cloth, a significant linear and positive relationship was found between the egg and caterpillar densities of the pest in the culture. Adults preferentially oviposited on the lower part of the soybean plants, while the caterpillars preferred to position themselves predominantly in the lower and mid region of the plants. However, at warmer temperatures during the day, the caterpillars migrate to the upper areas of the soybean plants.
\end{abstract}

\section{Keywords}

Glycine Max, Monitoring, Sexual Pheromone, Behavior

\section{Introduction}

In the past, the soybean looper Chrysodeixis includens (Walker) (Lepidoptera: 
Noctuidae) was considered as a secondary pest in soybean cultivation in Brazil [1] [2]. However, from the $2003 / 2004$ crop, this species became a key pest in the growth due to frequent population outbreaks and damage to cultivated areas [3].

Pest monitoring is the basis of integrated pest management and it is through this that control tactics are implemented or not in crops [4]. The use of traps baited with synthetic sex pheromone is considered a practical method for pest monitoring [5]. Researches with the Spodoptera frugiperda (Smith) (Lepidoptera: Noctuidae) in corn recommend that the chemical control of this caterpillar should be carried out ten days after the cumulative capture of three moths per pheromone trap [6].

The difficulties of controlling the soybean looper in the soybean crop are related to the behavior that this pest presents to remain, preferably, in the lower canopy of the soybean plants, mainly in the abaxial face of the leaves, which makes its control difficult by plant spraying with insecticides [7]. Conducting researches on the vertical distribution of pest insects may improve monitoring and assist in the development of control tactics. In addition, this information may indicate the best time or place for spraying insecticides to maximize pest control [8]. Thus, the objective of this work was to obtain information on population fluctuations, relationships between adults and immatures in the crop as well as the vertical distribution of the soybean looper on the foliar canopy of the soybean crop, aiming to provide subsidies to be used in the integrated management of this plague.

\section{Materials and Methods}

The experiment was carried out under field conditions in the experimental area of the Embrapa Agropecuária Oeste, in the Dourados-MS (Latitude 22 $16^{\prime} 30^{\prime \prime}$ and Longitude $\left.54^{\circ} 49^{\prime} 0^{\prime \prime}\right)$, during the soybean crop of 2014/2015. The cultivar Brasmax Potência RR, without seed treatment, was planted in an area of approximately one hectare on October 28, 2014, according to the technical recommendations for cultivation in the region, with humid sub-tropical climate.

\subsection{Population Fluctuation and Correlation of Adults and Immatures}

The adults of the soybean looper, Chrysodeixis includens, were monitored during the period from October 2014 to October 2015 in the soybean crop. The capture of moths was done using Delta traps (Biocontrole ${ }^{\circledast}$ ) with adhesive floors, baited with the sexual pheromone Bio pseudoplusia (Biocontrole ${ }^{\varpi}$ ). Traps were inspected weekly for captured moth counts, while the adhesive floors were also changed, and the pheromone septa were replaced every twenty-one days.

Eggs and caterpillars were visually monitored on the soybean plants shortly after their emergence. In the sampling of caterpillars, the beat cloth was used and carried out two to three times per week with five beats of cloth next to each pheromone trap. The captured caterpillars were classified as large $(\geq 1.5 \mathrm{~cm})$ or 
small $(<1.5 \mathrm{~cm})$. At each sampling period, two plants close to each trap were also removed and taken to the entomology laboratory for inspection of the eggs on the leaves and stems. Adult trapping data on the traps and their immature forms found in soybean plants were submitted to linear regression analysis.

The weekly means of catching adults in the traps and their immature forms found in soybean plants were submitted to Pearson correlation analysis, linear regression and descriptive statistical analysis.

\subsection{Vertical Distribution of Caterpillars}

Eggs and caterpillars of $C$. includens were sampled in the soybean plants during flowering of the crop from six o'clock in the morning. For this, ten plants were collected and sectioned in three extracts (lower, middle and upper), which were bagged separately and taken to the laboratory for egg and caterpillar counts. The same procedure was repeated at $8 \mathrm{am}, 10 \mathrm{am}$, noon, $2 \mathrm{pm}, 4 \mathrm{pm}, 6 \mathrm{pm}$ and $8 \mathrm{pm}$ each day. For the analysis of the movement of caterpillars between plant extracts throughout the day, the upper, middle and lower parts of the plants were considered the treatments to be evaluated, and the number of plants the 160 plants collected on the two days of sampling were evaluated, the replicates of the test conducted in the completely randomized design, after checking the normality of the means, they were compared by the Tukey test at the $5 \%$ probability level.

\section{Results and Discussion}

\subsection{Population Fluctuation and Adult-Immature Relationships in Soybean}

During the whole monitoring period, $1.199 \mathrm{C}$. includens moths were captured, the presence of this species being observed in all the months of the year, including the period of the planting to the soybean harvest, as well as in the off-season where second corn crop and brachiaria were grown in the studied area (Figure $1)$.

In the period of soybean cultivation (October/2014 to February/2015), the number of moths captured was significantly higher, with the highest occurrence of adults being observed in the months of January to February (Figure 1), when the soybean was in the reproductive stage. In April, the second peak of moths was observed, when the area was being cultivated. These adults from the second peak probably came from other nearby soybean plantations that had not yet been harvested. It is noted that the soybean crop offered the best conditions for the development of the soybean looper, which resulted in the increase of the population of moths in this crop in comparison with the other periods of sampling.

The soybean looper is considered a polyphagous pest, since it feeds on and develops in about 170 species of host plants belonging to 39 families [9]. This fact explains the survival of this pest in the period of when it would be feeding on other host plants. The species has already been observed attacking beans, tomato, 


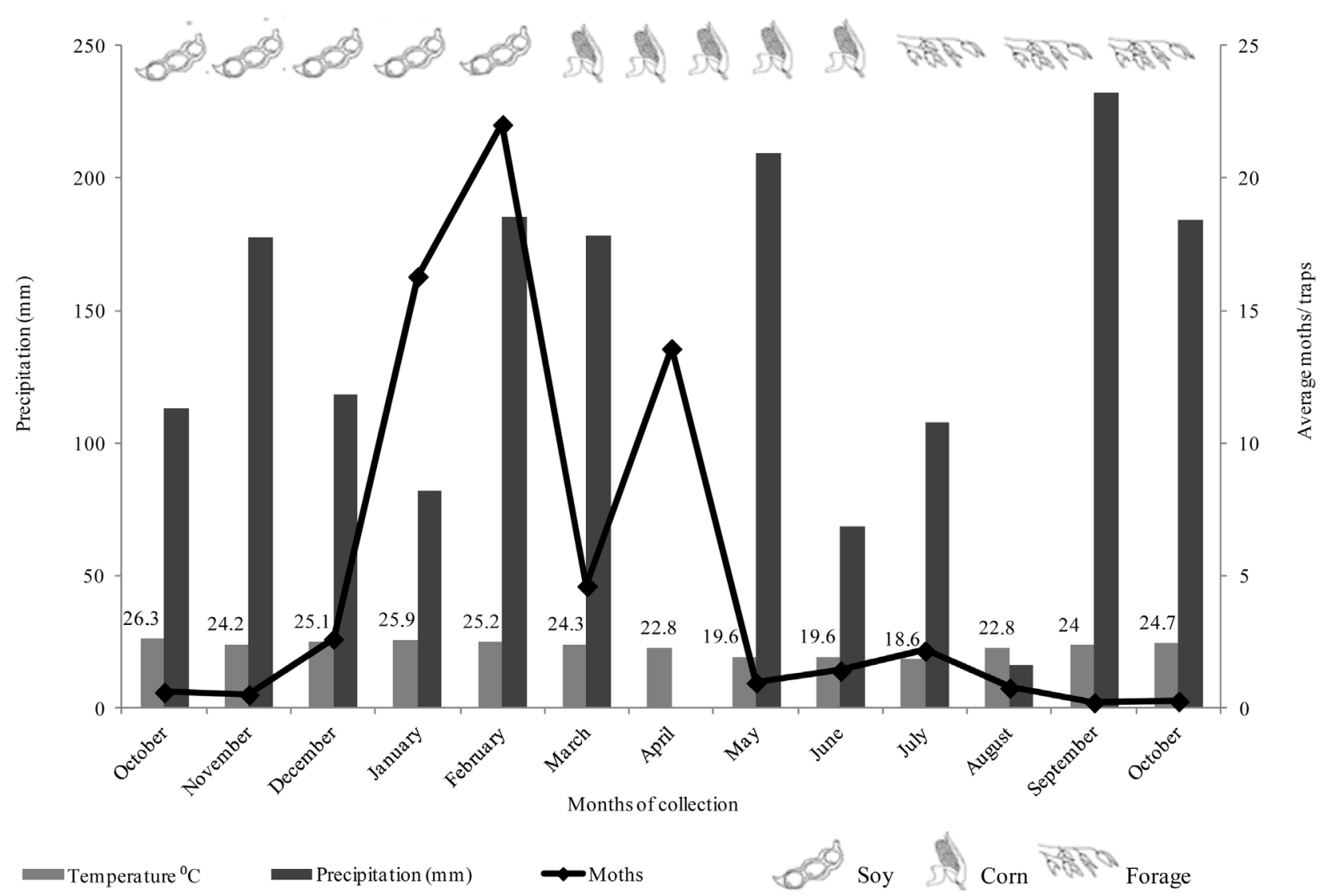

Figure 1. Population fluctuation of Chrysodeixis includens adults caught in sexual pheromone traps, mean temperatures and monthly precipitation observed from October 2014 to October 2015. Dourados, MS.

tobacco, sunflower, cauliflower, lettuce, as well as soybean, cotton, corn and others [10] [11]. However, researches have shown that $C$. includens has greater preference and adaptation to soybean when compared to other cultures in which it has already been verified [12].

The occurrence of this species throughout the year in the region may also be linked to climatic conditions favorable to its development. Among the main caterpillars of the subfamily Plusiinae, $C$. includens seems to be better adapted to warmer regions, compared to Rachiplusia nu (Guenée), which occurs more frequently in colder regions [13]. In Brazil, outbreaks of $C$. includens occur frequently in western Bahia, Goiás, Mato Grosso, Mato Grosso do Sul, São Paulo, Paraná and Rio Grande do Sul, but lack information on the mobility of this species in tropical conditions, especially during the soybean off season [14].

The first eggs and caterpillars of $C$. includens were observed in November between the V2 and V3 phenological stages of soybean plants, while adult, egg and caterpillar peaks in soybean were observed during the month of January (Figure 2). These results show that the population explosion of this pest occurs when the soybean plants usually enter the reproductive stage and have a "closed" canopy. The month of January presented a lower precipitation $(82 \mathrm{~mm})$ when compared to the other months of soybean cultivation (Figure 1). It is known 


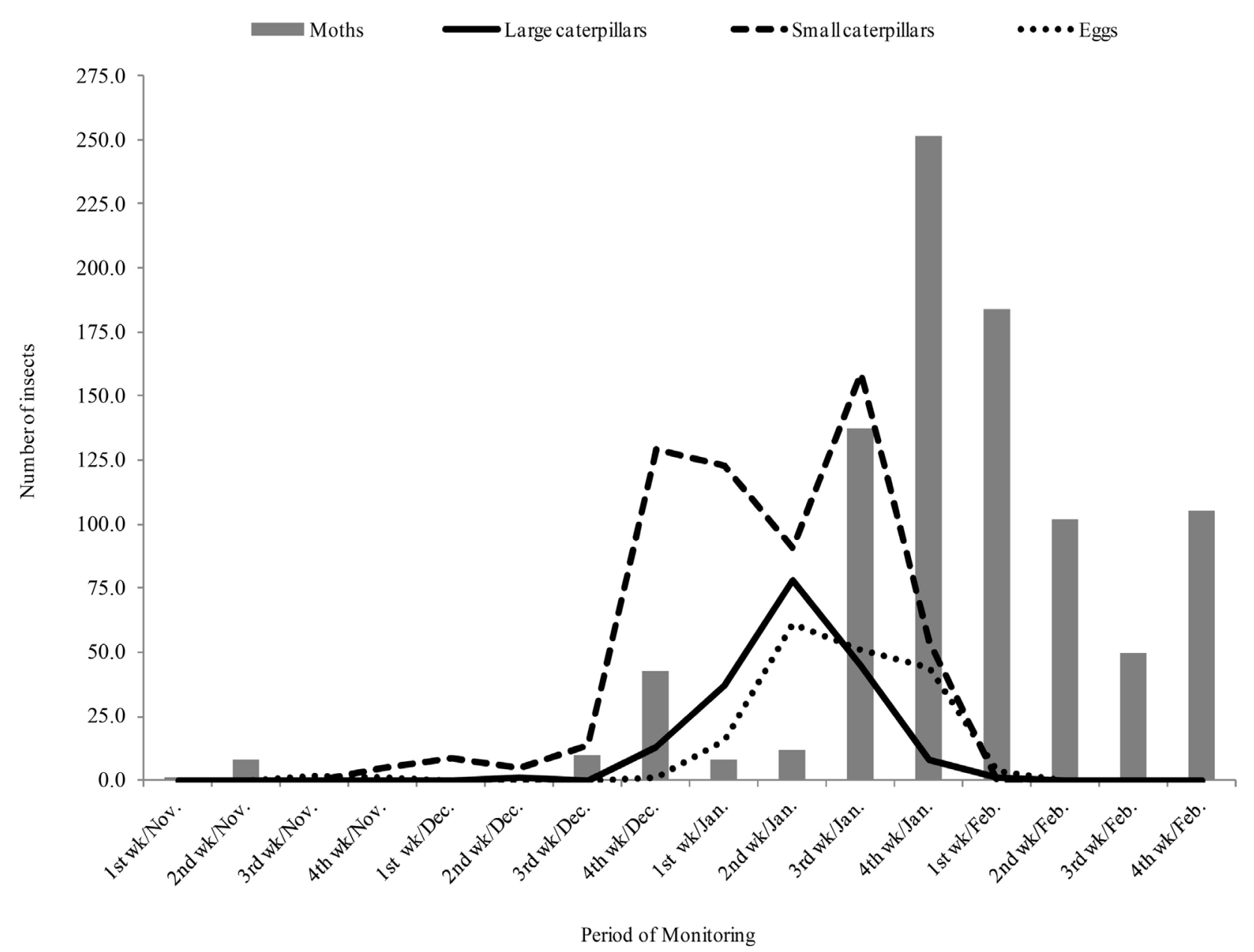

Figure 2. Population fluctuation of adults and immature forms of Chysodeixis includens in soybean crops during the 2014/2015 harvest. Dourados, MS.

that $C$. includens is favored by conditions of low precipitation or periods of drought that precede the outbreaks of this pest [11] [15], as was also observed in this research.

Different authors observed greater average density of $C$. includens eggs in the stage of full bloom of the soybean (R2), similar to the one found in this study [16] [17]. Regarding the number of caterpillars, researches by [18], in several cities of Rio Grande do Sul, by [19], in IlhaSolteira in the State of São Paulo and by [20] in the state of Tocantins, also reported higher density of caterpillars in the reproductive period of the crop. However, these results differed from those observed in the State of Roraima by [21], which verified the population peaks of $C$. includens caterpillars in the vegetative phase of the crop.

The number of $C$. includens adults caught in the pheromone traps was higher than that of eggs and caterpillars sampled in the soybean from the fourth week of January to the end of the soybean growing period (Figure 2). This was because the adults probably migrated from other planted areas of the region, especially medium and late-season soybean cultivars, attracted by the pheromone 
present in the traps. Researches conducted in the northern hemisphere have indicated that $C$. includens moths can fly long distances presenting great dispersal capacity in the regions [22] [23].

The relationships between moths caught in the pheromone-trapped traps and the immature densities sampled in the soybean crop in this study were not significant. However, a linear and significant relationship was observed between the egg and caterpillar densities of this pest (Figure 3). [24] found curvilinear relationships between trapped males of Plutella xylostella (L.) (Lepidoptera: Plutellidae) and density of larvae and pupae in canola (Brassica napus L.) in Canada, while [25] found nonlinear relationships between moths caught in pheromone and immature traps of Malacosoma dysstria (Hübner) (Lepidoptera: Lasiocampidae), a pest that attacks the poplar (Populus tremuloides Michx. (Salicales: Salicaceae).

A number of factors may influence the development of a predictive strategy with pheromones, including geographic variation [26], the impact of natural enemies on the pest population [27], the climatic conditions and the quality of the pest host plant [28].

Based on the results, it can be inferred that the egg sampling in the soybean plants would be the best option to estimate the infestation of caterpillars in the crop. However, $C$. includens eggs are difficult to monitor because they are very small and measure about $0.5 \mathrm{~mm}$ in diameter [14], which makes this parameter inapplicable for monitoring caterpillars in soybean, and it is therefore more practical to sample the caterpillars using the beat cloth. In the conditions in which this work was carried out, the pheromone traps were effective in the detection of $C$. includens adults, important information since we know that the presence of adult in the culture predates the occurrence of eggs and caterpillars. However, there was no significant relationship between the adult population and immature densities that made it possible to estimate caterpillar or egg infestation in soybean plants by using the adult population density found in pheromone traps.

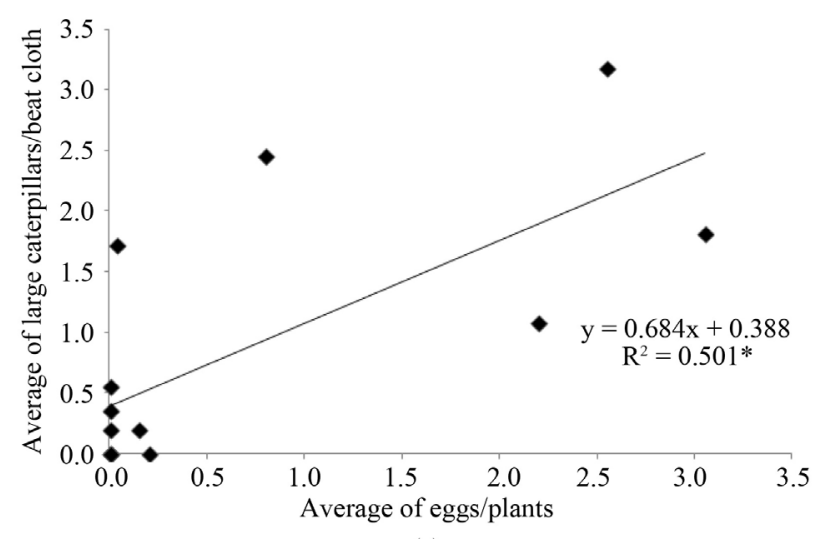

(a)

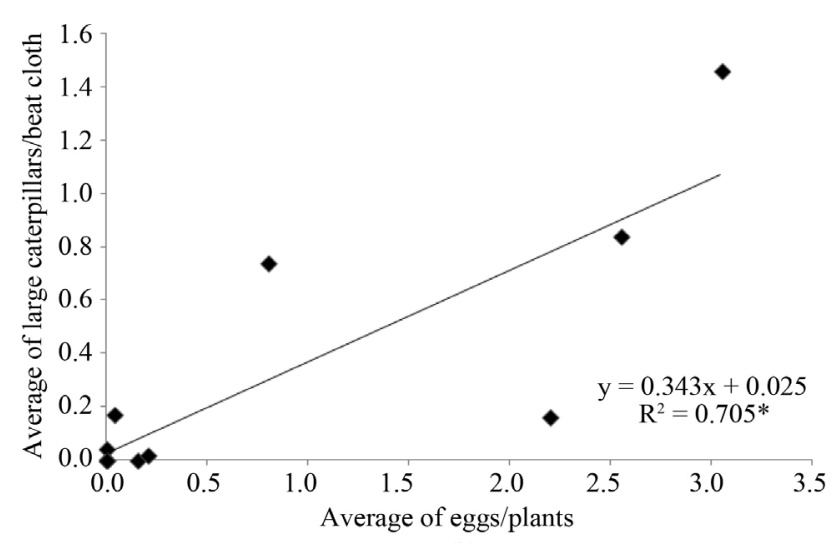

(b)

Figure 3. Linear regression between population density of eggs and caterpillars (a) of eggs and large caterpillars; (b) of Chrysodeixis includens sampled in the soybean crop in the 2014/2015 harvest. Dourados, MS. 


\subsection{Vertical Distribution of Eggs and Caterpillars in Soybean}

The $C$. includens moths were oviposited in all three extracts (lower, middle and upper) of the soybean plants, but the eggs were deposited in greater quantity in the lower extract, when compared to the medium and upper extracts, which presented similar oviposition rates (Figure 4). A total of 450 eggs were sampled in the collected plants, $61.3 \%$ of which were in the lower third, $24.8 \%$ in the medium and $13.8 \%$ in the upper one.

These results corroborate the research done by [29], who observed a higher number of $C$. includens eggs in the lower third of the soybean plants. [30] observed higher deposition of soybean loopereggs in the median region of the plants, while [17] showed higher oviposition of $C$. includens in the middle and higher parts of the soybean, similar to the results found by [31], whereas [32], did not observe a difference in egg deposition among these three extracts of the plant.

When the soybean plants are in full flowering stage, the crop is closed. In this condition, the plants grow and approach each other closing the leaf canopy, leaving the lower part of the plants more protected [29]. Moths preferentially deposited their eggs in the lower part followed by the middle part of the plants, probably due to the protection that this environment confers on its immature ones, when they are less exposed to the climatic adversities, the dehydration as

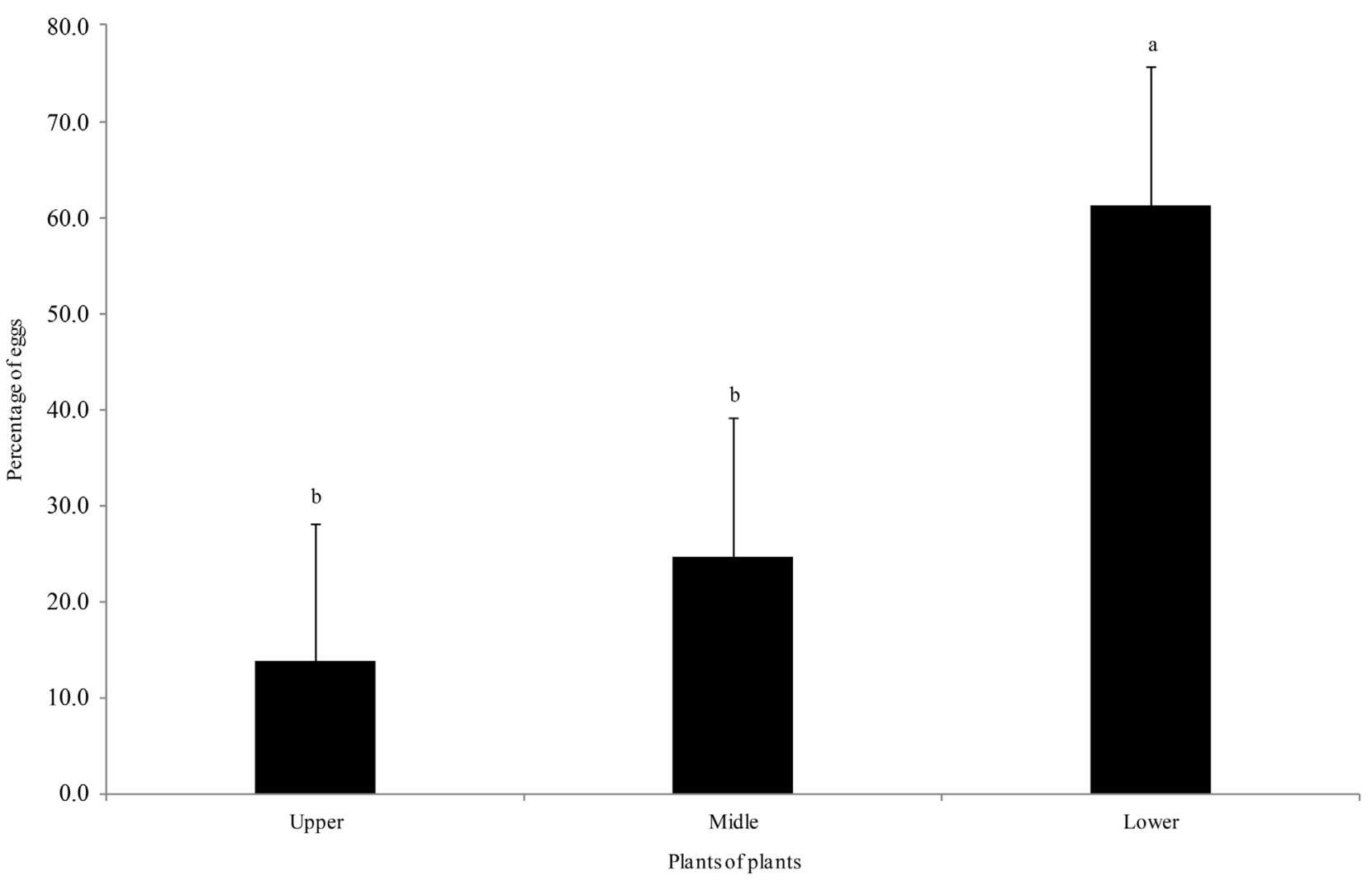

Figure 4. Vertical distribution of Chrysodeixis includens eggs in the profile of soybean plants in the 2014/2015 harvest. Dourados, MS. Bars followed by different letters, the values differ statistically by the Tukey's test at $5 \%$ probability. 
well as the access of possible natural enemies and the chemical control.

In the researches of vertical distribution of $C$. includens caterpillars, 282 insects were sampled, being 186 small caterpillars and 96 large caterpillars. Regardless of the size of the caterpillars, they were distributed in the plant profile, preferably in the lower third, followed by the middle third, similar to that observed for the oviposition behavior (Figure 5). The caterpillars have a preference for the lower part of the plants, probably because in this environment they are more protected from natural enemies and from climatic adversities. [32] observed that regardless of the size of the caterpillars, they found no difference in the distribution of $C$. includens in the extracts of the soybean plants. However, [33] found that soybean looper usually feed on the lower third of soybean plants, as was also observed in this work. [34], in researches with $A$. gemmatalis, reported the displacement of caterpillars, as they develop, to the higher regions of plants. It should be noted that this behavior of caterpillars makes it difficult to control them by applying insecticides because these caterpillars are less exposed to contact with insecticides when applied to soybean, especially when the crop is in the reproductive stage where the top of the plants is closed (Figure 1), which can be used as a barrier for the penetration of spray droplets, known as "the

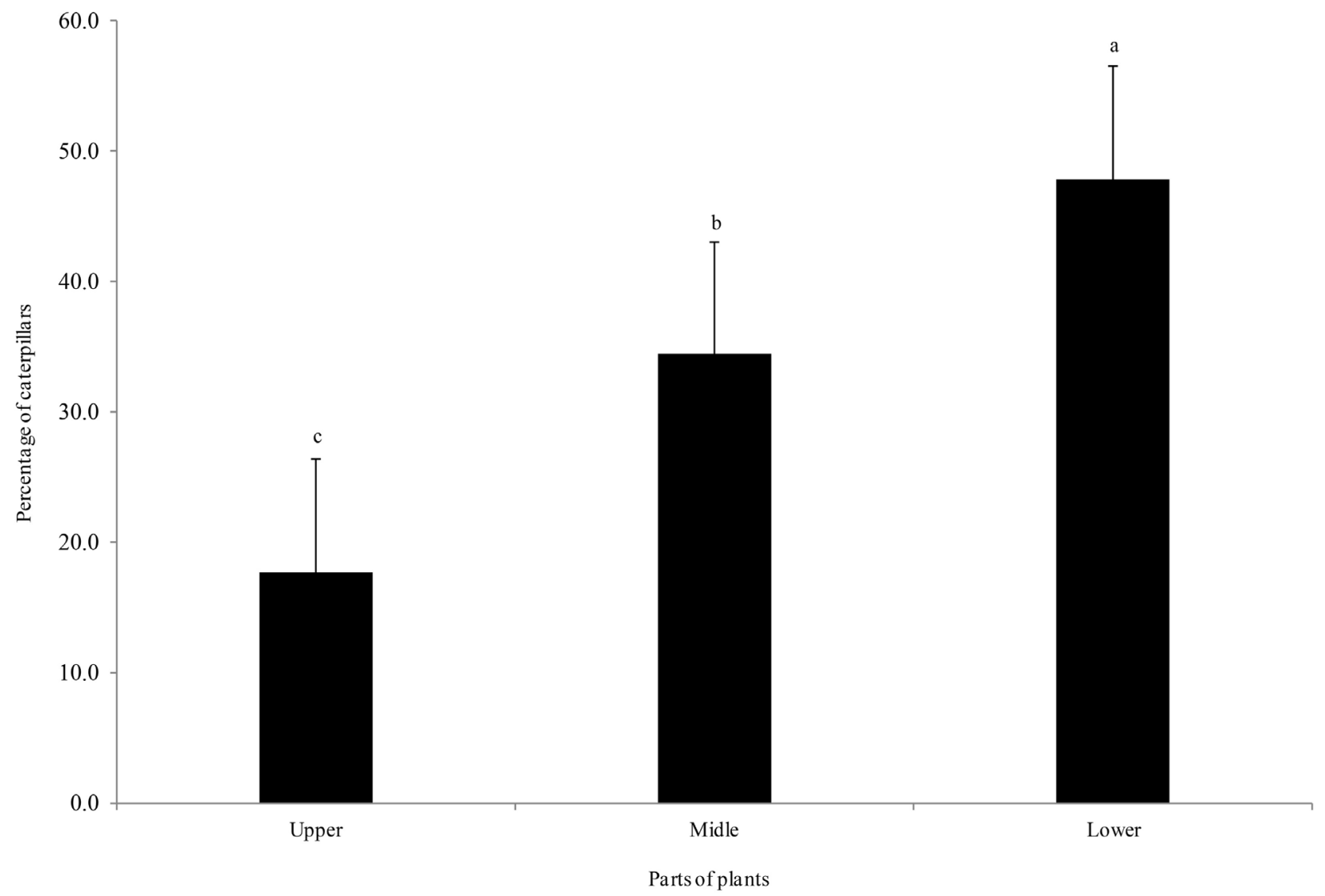

Figure 5. Vertical distribution of total (large + small) Chrysodeixis includens caterpillars in the profile of soybean plants in the 2014/2015 crop. Dourados, MS. Bars followed by different letters, the values differ statistically by the Tukey's test at $5 \%$ probability. 


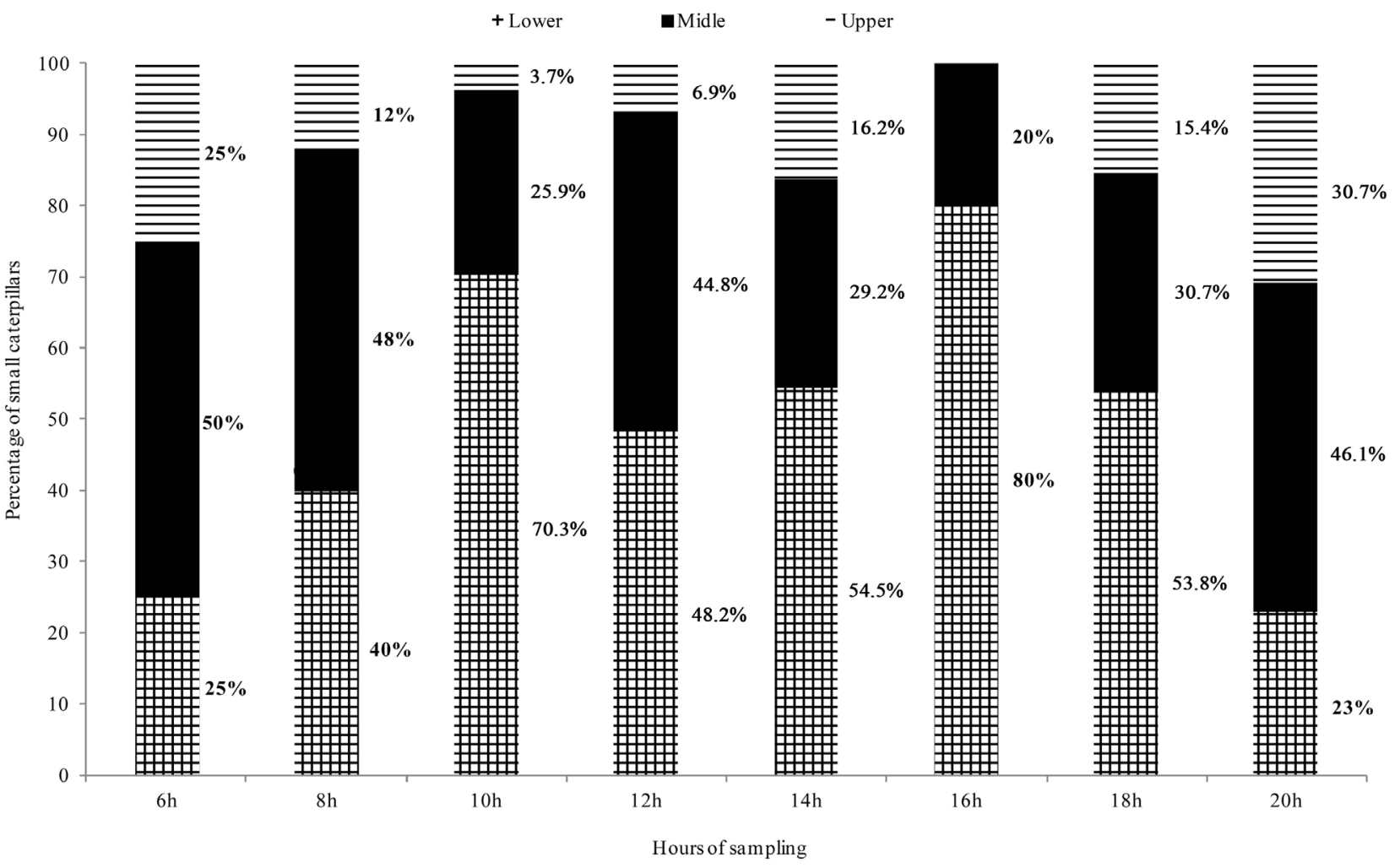

Figure 6. Vertical distribution of small Chrysodeixis includens caterpillars throughout the day in the profile of soybean plants in the 2014/2015 harvest. Dourados, MS. 


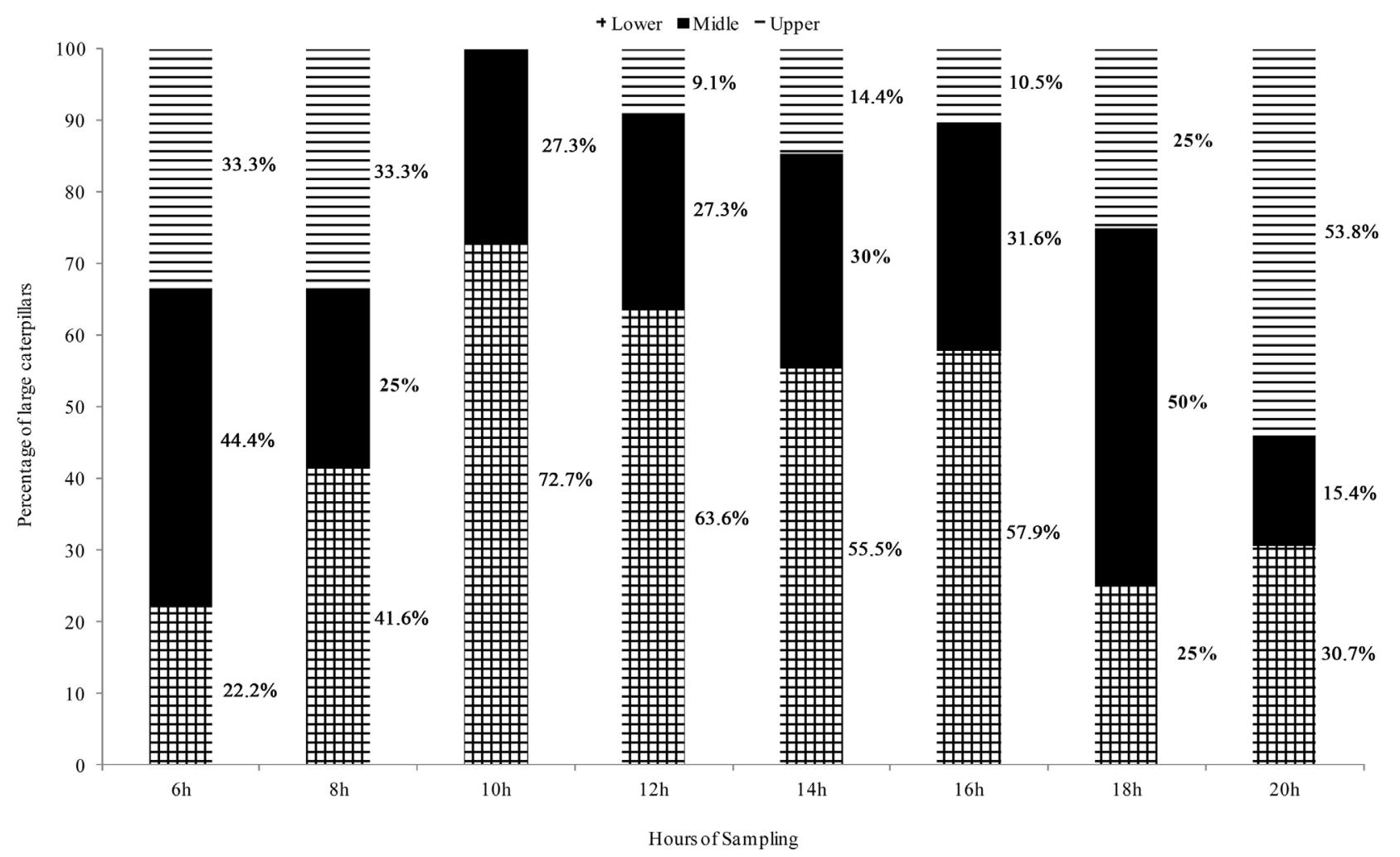

Figure 7. Vertical distribution of large Chrysodeixis includens caterpillars throughout the day in the profile of soybean plants in the 2014/2015 crop. Dourados, MS.

caterpillars the behavior is similar, since at $20 \mathrm{~h}$ more than $50 \%$ of the caterpillars were concentrated in the upper plant extract (Figure 7). This information is extremely important especially for the management of large $C$. includens caterpillars in the soybean crop since these caterpillars are more difficult to control than small ones.

Researches on the behavior of soybean looper throughout the day are scarce. However, [37] reported on the dietary behavior of $C$. includens caterpillars that the activity of searching for food extended throughout the 24 hours of the day, intensifying at the end of the evening period.

According to the results obtained in this work, it can be inferred that the chemical control of large and small soybean looper should be carried out preferentially in the first hours of the day or at dusk, since in these periods, the caterpillars are more exposed to contact with the products sprayed in the culture. The most successful cases of chemical control of the soybean looper in drought periods are more common with nocturnal sprays and good plant cover [38].

\section{Conclusion}

Chrysodeixis includens adults can be found practically all year round in the region of Dourados, MS, but the peak of their occurrence and immature forms is observed in the months of January and February. There is a significant and positive linear relationship between the density of $C$. includens eggs and the densities 
of small caterpillars and large caterpillars in soybean plants. C. includens females have preference in ovipositing in the inferior part of the soybean plants. Small and large $C$. includens caterpillars usually remain in a larger proportion in the lower part of the soybean plants, in relation to the median and upper parts. However, during the day, these caterpillars move in the profile of the soybean plants, being more exposed in the medium and upper extracts at times of milder temperatures, especially for large caterpillars.

\section{References}

[1] Sosa-Gómez, D.R., Delpin, K.E., Moscardi, F. and Nozaki, M.H. (2003) The Impact of Fungicides on Nomuraea rileyi (Farlow) Samson Epizootics and on Populations of Anticarsia gemmatalis Hübner (Lepidoptera: Noctuidae), on Soybean. Neotropical Entomology, 32, 287-291. https://doi.org/10.1590/S1519-566X2003000200014

[2] Sosa-Gómez, D.R., LópezLastra, C.C. and Humber, R.A. (2010) An Overview of Arthropod-Associated Fungi from Argentina and Brazil. Mycopathologia, 170, 61-76. https://doi.org/10.1007/s11046-010-9288-3

[3] Bueno, R.C.O.F., Parra, J.R.P., Bueno, A.F. and Haddad, M.L. (2009) Desempenho de Trichogramatídeos como potenciais agentes de controle de Pseudoplusia includens Walker (Lepidoptera: Noctuidae). Neotropical Entomology, 38, 389-394. https://doi.org/10.1590/S1519-566X2009000300015

[4] Bortolotto, O.C., Fernandes, A.P., Bueno, R.C.O.F., Bueno, A.F., Kruz, Y.K.S., Queiroz, A.P., Sanzovo, A. and Ferreira, R.B. (2015) The Use of Soybean Integrated Pest Management in Brazil: A Review. Agronomy Science and Biotechnology, 1, 25-32.

[5] Zarbin, P.H.G., Rodrigues, M.A.C.M. and Lima, E.R. (2009) Feromônios de insetos: tecnologia e desafios para uma agricultura competitiva no Brasil. Química Nova, 32, 722-731. https://doi.org/10.1590/S0100-40422009000300016

[6] Cruz, I., Figueiredo, M.L.C., Silva, R.B. and Foster, J.E. (2010) Efficiency of Chemical Pesticides to Control Spodoptera frugiperda and Validation of Pheromone Trap as a Pest Management Tool in Maize Crop. Revista Brasileira de Milho e Sorgo, 9 , 107-122. https://doi.org/10.18512/1980-6477/rbms.v9n2p107-122

[7] Oliveira, J.R.G., Ferreira, M.C. and Román, R.A.A. (2010) Diferentes diâmetros de gotas e equipamentos para aplicação de inseticida no controle de Pseudoplusia includens. Engenharia Agrícola, 30, 92-99. https://doi.org/10.1590/S0100-69162010000100010

[8] Fernandes, M.G., Silva, A.M., Degrande, P.E. and Cubas, A.C. (2006) Distribuição vertical de lagartas de Alabama argillacea (Hubner) (Lepidoptera: Noctuidae) em plantas de algodão. Manejo Integrado de Plagas y Agroecología, 78, 28-35.

[9] Specht, A., Paula-Morais, S.V. and Soza-Gomez, D.R. (2015) Host Plants of Chrysodeixis includes (Walker) (Lepidoptera, Noctuidae, Plusiinae). Revista Brasileira de Entomologia, 59, 343-345. https://doi.org/10.1016/j.rbe.2015.09.002

[10] Herzog, D.C. and Todd, J.H. (1980) Sampling Velvetbean Caterpillar on Soybean. In: Kogan, M. and Herzog, D.C., Eds., Sampling Methods in Soybean Entomology, Springer-Verlag, Berlin, 107-140. https://doi.org/10.1007/978-1-4612-9998-1_6

[11] Carvalho, L.C., Ferreira, F.M. and Bueno, N.M. (2012) Importância econômica e generalidades para o controle da lagarta falsa-medideira na cultura da soja. EnciclopédiaBiosfera-Centro CientíficoConhecer, 8, 1021.

[12] Bernardi, O., Malvestiti, G.S., Dourado, P.M., Oliveira, W.S., Martinelli, S., Berger, 
G.U., Head, G.P. and Omotoa, C. (2012) Assessment of the High-Dose Concept and Level of Control Provided by MON $87701 \times$ MON 89788 Soybean against Anticarsia gemmatalis and Pseudoplusia includens (Lepidoptera: Noctuidae) in Brazil. Pest Management Science, 68, 1083-1091. https://doi.org/10.1002/ps.3271

[13] Bercellini, N. and Malacalza, L. (1994) Plagas y depredadores en soja enel noroeste de laProvincia de Buenos Aires (Arg.). Turrialba, 44, 244-254.

[14] Moscardi, F., Bueno, A.F., Sosa-Gómez, D.R., Roggia, S., Hoffman-Campo, C.B., Pomari, A.F., Corso, I.C. and Yano, S.A.C. (2012) Artrópodes que atacam as folhas da soja. In: Hoffman-Campo, C.B., Corrêa-Ferreira, B.S. and Moscardi, F., Eds., Soja: manejo integrado de insetos e outros artrópodes-pragas, Embrapa, 859.

[15] Bueno, R.C.O.F., Bueno, A.F., Moscardi, F., Parra, J.R.P. and Hoffmann-Campo, C.B. (2011) Lepidopteran Larvae Consumption of Soybean Foliage: Basis for Developing Multiple Species Economic Thresholds for Pest Management Decisions. Pest Management Science, 67, 170-174. https://doi.org/10.1002/ps.2047

[16] Felland, C.M., Porter, R.P. and Pitre, H.N. (1992) Soybean Looper (Lepidoptera: Noctuidae) Oviposition Preference Relative to Plant Development in Soybean and Cotton. Journal of Entomological Science, 27, 217-223. https://doi.org/10.18474/0749-8004-27.3.217

[17] Mascarenhas, R.N. and Pitre, H.N. (1997) Oviposition Responses of Soybean Looper (Lepidoptera: Noctuidae) to Varieties and Growth Stages of Soybean. Environmental Entomology, 26, 76-83. https://doi.org/10.1093/ee/26.1.76

[18] Moraes, R.R., Loeck, A.E. and Belarmino, L.C. (1991) Flutuação populacional de Plusiinae e Anticarsia gemmatalis Hübner, 1818 (Lepidoptera: Noctuidae) em soja no Rio Grande do Sul. Pesquisa Agropecuária Brasileira, 26, 51-56.

[19] Campos, O.R., Campos, A.R. and Lara, F.M. (1997) Predadores entomófagos em duas variedades de soja [Glycinemax (L.) Merrill], na região de Ilha Solteira SP. Cultura Agronômica, 6, 1.

[20] Didonet, J., Sarmento, R.A., Aguiar, R.W.S., Santos, G.R. and Erasmo, E.A.L. (2003) Abundância de pragas e inimigos naturais em soja na região de Gurupi, Brasil. Manejo Integrado de Plagas y Agroecologia, 69, 50-57.

[21] Marsaro Junior, A.L.M., Pereira, P.R.V.S., Silva, W.R. and Griffel, S.C.P. (2010) Flutuação populacional de insetos-praga na cultura da soja no Estado de Roraima. Revista Acadêmica de Ciências Agrárias Ambientais, 8, 71-76. https://doi.org/10.7213/cienciaanimal.v8i1.10538

[22] Harding, J.A. (1976) Seasonal Occurrence, Parasitism and Parasites of Cabbage and Soybean Loopers in the Lower Rio Grande Valley. Environmental Entomology, 5, 672-674. https://doi.org/10.1093/ee/5.4.672

[23] Mason, L.J., Johnson, S.J. and Woodring, J. (1989) Seasonal and Ontogenetic Examination of the Reproductive Biology of Pseudoplusia includens (Lepidoptera: Noctuidae). Environmental Entomology, 18, 980-985.

https://doi.org/10.1093/ee/18.6.980

[24] Miluch, C.E., Dosdall, L.M. and Eveden, M.L. (2013) The Potential for Pheromone-Based Monitoring to Predict Larval Populations of Diamondback Moth, Plutella xylostella (L.), in Canola (Brassica napus L.). Crop Protection, 45, 89-97. https://doi.org/10.1016/j.cropro.2012.11.023

[25] Jones, B.C., Roland, J. and Evenden, M. (2009) Development of a Combined Sex Pheromone-Based Monitoring System for Malacosoma disstria (Lepidoptera: Lasiocampidae) and Choristoneura conflictana (Lepidoptera: Tortricidae). Environmental Entomology, 38, 459-471. https://doi.org/10.1603/022.038.0220 
[26] Yang, C.Y., Lee, S., Choi, K.S., Heung, Y.J. and Boo, K.S. (2007) Sex Pheromone Production Response in Korean Populations of the Diamondback Moth, Plutella xylostella. Entomologia Experimentalis et Applicata, 124, 293-298. https://doi.org/10.1111/j.1570-7458.2007.00580.x

[27] Nofemela, R.S. (2010) The Ability of Synthetic Sex Pheromone Traps to Forecast Plutella xylostella Infestations Depends on Survival of Immature Stages. Entomologia Experimentalis et Applicata, 136, 281-289. https://doi.org/10.1111/j.1570-7458.2010.01029.x

[28] Cruz, I., Figueiredo, M.L.C., Silva, R.B., Silva, I.F., Paula, C.S. and Foster, J.E. (2012) Using Sex Pheromone Traps in the Decision-Making Process for Pesticide Application against Fall Armyworm (Spodoptera frugiperda [Smith] [Lepidoptera: Noctuidae]) Larvae in Maize. International Journal of Pest Management, 58, 83-90. https://doi.org/10.1080/09670874.2012.655702

[29] Pansera-de-Araújo, M.C.G., Da Cruz, I.B.M., Cavalheiro, M. and Oliveira, A.K. (1999) Placement of Noctuid Eggs (Lepidoptera) on Soybean Plants. Annals of the Entomological Society of America, 92, 702-706. https://doi.org/10.1093/aesa/92.5.702

[30] Valverde, L. (2007) Abundancia y distribución de loshuevos de lãs principales espécies de lepidópteros noctuidos plagas em El cultivo de soja em Tucumán, Argentina. Boletín de Sanidad Vegetal Plagas, 33, 163-168.

[31] Jost, D.J. and Pitre, H.N. (2002) Soybean Looper (Lepidoptera: Noctuidae) Oviposition on Cotton and Soybean of Different Growth Stages: Influence of Olfactory Stimuli. Journal of Economic Entomology, 95, 286-293. https://doi.org/10.1603/0022-0493-95.2.286

[32] Hamadain, E.I. and Pitre, H.N. (2002) Oviposition and Larval Behavior of Soybean Looper, Pseudoplusia includens (Lepidoptera: Noctuidae), on Soybean with Different Row Spacings and Plant Growth Stages. Journal Agricola Urban Entomology, 19, 29-44.

[33] Herzog, D.C. (1980) Sampling Soybean Looper on Soybean. In: Kogan, M. and Herzog, D.C., Eds., Sampling Methods in Soybean Entomology, Springer-Verlag, New York, 141-168. https://doi.org/10.1007/978-1-4612-9998-1_7

[34] Ferreira, B.S.C. and Panizzi, A.R. (1978) Distribuição de ovos e lagartas de Articarsia gemmatalis Hübner em plantas de soja. Anais da Sociedade Entomológica do Brasil, 7, 54-59.

[35] Gallo, D., Nakano, O., Silveira Neto, S., Carvalho, R.P.L., Baptista, G.C., Berti Filho, E., Parra, J.R.P., Zucchi, R.A., Alves, S.B.,Vendramim, J.D., Marchini, L.C., Lopes, J.R.S. and Omoto, C. (2002) Entomologia Agrícola. FEALQ, Piracicaba, 920 p.

[36] Polato, S.A. and Oliveira, N.C. (2011) Eficiência do controle da lagarta-do-cartucho na cultura do milho em função de diferentes horários de aplicação de inseticida. Campo Digital, 6, 44-53.

[37] Oliveira, A.P.S., Santos, R.S.S. and Bof, M.I.C. (2013) Ritmos circadianos e preferência pela busca de alimento de larvas de Chrysodeixis includens (Walker, 1857) (Lepidoptera: Noctuidae). Comunicata Scientiae, 4, 263-269.

[38] (2011) Soybean Production Technologies-Central Region of Brazil 2012 and 2013. Embrapa Soja, Londrina, 261 p. (Embrapa Soja. Sistemas de Produção, 15) 